\title{
INDIA IN 2002
}

\section{The BJP's Faltering Mandate and the Morphology of Nuclear War}

\section{Lawrence Sáez}

\begin{abstract}
This article surveys some of the critical events that took place in India in 2002, paying particular attention to India's uneasy relationship with Pakistan. It also evaluates the significance of internal political developments, such as the significance of state assembly elections and the occurrence of riots in Gujarat. The survey concludes with a brief examination of India's economic developments.
\end{abstract}

The landscape of international politics was purportedly changed after the terrorist attacks of September 11, 2001. In this context, South Asia became a centerpiece in the effort to eradicate terrorism. In the immediate aftermath of September 11, India was among the most vocal supporters of U.S. intervention in Afghanistan. By the end of 2002, though, familiar patterns of India's political regime had reemerged. At the domestic level, there was a revival of communal riots. Results from state assembly elections indicated evidence of a gradual collapse of popular support for the governing coalition at the center. At the international level, the year brought about a reactivation of border tensions with Pakistan, as well as an unexpected improvement in economic growth.

\section{Indo-Pakistani Conflict}

The year 2002 started ominously, amid heightened tensions between India and Pakistan. In January, India mounted a diplomatic offensive claiming that

Lawrence Sáez is Senior Associate Member, at St. Antony's College, and South Asia Visiting Fellow, Queen Elizabeth House, University of Oxford. He is also Visiting Research Fellow, Center for International Studies, London School of Economics. The author would like to thank Steve Heim and Katharine Adeney for their comments.

Asian Survey, 43:1, pp. 186-197. ISSN: 0004-4687

(C) 2003 by The Regents of the University of California. All rights reserved.

Send Requests for Permission to Reprint to: Rights and Permissions, University of California Press, Journals Division, 2000 Center St., Ste. 303, Berkeley, CA 94704-1223. 
the December 13, 2001, attack on its parliament was tacitly supported by Pakistan. Shortly after the attack, India recalled its ambassador to Pakistan. On January 1, 2002, India discontinued the Lahore bus service as well as the Samhauta Express train service, both important symbols of Indo-Pakistani détente. In one of the largest troop movements since the 1971 Indo-Pakistani war, India adopted a strategy of preclusive defense, namely, by massing the border with troops. Starting in January, as many as one-million Indian troops were stationed along the Line of Control (LOC) separating Indian- and Pakistani-held sections of Kashmir. In response, Pakistan also mobilized troops along its eastern border and across the LOC.

In the aftermath of the September 11 terrorist attacks, India expressed unconditional support for President Bush's actions in Afghanistan and provided support for his war on terrorism. The removal of sanctions that the U.S. had imposed in 1998-2002 after India and Pakistan tested nuclear weapons in May 1998 signaled a trend in American foreign policy to give priority to the issue of terrorism rather than non-proliferation.

The test of the Bush administration's commitment to the war on terrorism came about as a result of India's insistence that Pakistan cooperate with India on the release to New Delhi of accused terrorists based in Pakistan. This pressure became more intense on January 22, 2002, when the American Cultural Center in Calcutta (Kolkotta) was attacked by four gunmen who killed five police officers and injured 20 other individuals. The Islamic terrorist group Harkat-ul-Jehad-e-Islam (HuJeI, Movement for Islamic Struggle) claimed responsibility for the attack on the American center. Astonishingly, because no Americans were killed or harmed, the attack was merely portrayed as a domestic terrorist dispute and received little attention in the United States.

Nevertheless, India set out to unilaterally undertake an aggressive stance against terrorism. New Delhi issued a most-wanted list of 20 suspected terrorists. They included Ghazi Baba, the alleged mastermind of the attack on India's parliament on December 13, 2001, as well as the Srinagar bombing attack on October 1, 2002. Other suspected terrorists on the list included Aftab Ahmed Ansari, believed to be responsible for the January attack on the American Center in Calcutta. Ansari was later arrested in Dubai while traveling with a Pakistani passport, and eventually deported back to India for trial.

Relying on the much-contested international law concept of hot pursuit, India sought to capture terrorists living in Pakistan and in Pakistan-held territory in Kashmir. India also threatened to withdraw Most Favored Nation status and abrogate the Indus Water Treaty. The Pakistani response to Indian demands was predictably caustic. India, though, was surprised by the restraint that Washington showed in its demands that Pakistan cooperate with India on this matter. Eventually, the U.S. designated two Pakistani-based 
Kashmiri terrorist groups, Lashkar-e-Toiba (Army of the Pure, LeT), and Jaish-e-Mohammed [Legion of Mohammed, JeM], as foreign terrorist organizations. In turn, Pakistan outlawed these organizations.

After intensive pressure from international institutions and U.S. officials, the tensions between both countries appeared to attenuate somewhat, particularly after Pakistan's president, General Pervez Musharraf, and India's prime minister, Atal Bihari Vajpayee, shook hands on January 5, 2002, at a meeting of the South Asia Association for Regional Cooperation (SAARC) in Kathmandu, Nepal. Nevertheless, the threat of war between India and Pakistan had caused great concern among some American government officials. For instance, in testimony before the Senate Select Committee on Intelligence, Director of the Central Intelligence Agency George Tenet expressed alarm when he argued that "[t]he chance of war between these two nuclear-armed states is higher than at any point since 1971. If India were to conduct largescale offensive operations into Pakistani Kashmir, Pakistan might retaliate with strikes of its own in the belief that its nuclear deterrent would limit the scope of an Indian counterattack." Although Tenet acknowledged that India and Pakistan had underplayed the significance of the troop movements along the LOC, he added that "[w]e are deeply concerned, however, that a conventional war-once begun-could escalate into a nuclear confrontation."

The U.S. response to the January standoff was restrained, as it was largely viewed in Washington as stemming from India and Pakistan's long-standing tensions over Kashmir. In this light, the U.S. has attempted to provide some diplomatic help in resolving the Kashmir conflict. Assistant Secretary of State for South Asia Christine Rocca visited India in April to try to assess the effort to solidify potential future talks on the region.

Despite the initial external diplomatic efforts, the continuing war of words between Vajpayee and Musharraf hinted that the tensions were much deeper than presumed by most Washington officials. For instance, in an interview with the German magazine Der Spiegel, Musharraf hinted that he was prepared to use nuclear weapons in case of a war with India. He said that if the pressure was great, "In an emergency, even the atom bomb can also be considered."2

The border tensions between both countries were stoked by India's accusations that Pakistan was allowing border crossings into Indian-held territory in the disputed state of Kashmir. The objectives of the border crossings soon became apparent. On March 30, an Islamic Front suicide squad entered the Raghunath Temple in Jammu, killing eight people. Two weeks later, on May

1. Tenet's full testimony before the Senate Intelligence Committee on February 6, 2002, can be found at <http://www.cia.gov/cia/public_affairs/speeches/dci_speech_02062002.html>.

2. Translation from the German by the author. Der Spiegel, April 8-15, 2002, p. 170. 
14, bilateral tensions reached a new height after an attack on Indian military personnel near the Kaluchak army camp in Jammu. Posing as Indian soldiers, three terrorists opened fire on a bus carrying Indian army personnel and their families, killing 32 people and wounding 43 others.

The escalation of terrorist attacks in Jammu elicited an aggressive response from New Delhi. By the end of May, Indian government officials openly discussed the possibility of crossing the LOC and launching air strikes against suspected terrorist camps in Pakistan-held Kashmir. A more elaborate plan, comically dubbed Operation Salami Slice, proposed a joint air and infantry attack across the LOC in order to destroy the terrorist camps that dot the region.

The escalation of border tensions led to a familiar brand of rhetorical brinkmanship. In a May 22 speech before Indian troops stationed in Kupwara, near the scene of the May 14 attack, Vajpayee expressed rage at the massacre and declared that "[w]e know how to respect the enemy. But it should not be construed as our weakness, nor should anyone think that we would indefinitely go on tolerating things." He concluded that "our aim should be victory - as the time has come to fight a decisive battle." 3

A day after his speech at Kupwara, Vajpayee began to backtrack from the impassioned remarks he made before his soldiers. In a chaotic press conference held in Srinagar, Vajpayee was asked repeatedly what he meant by the words "decisive battle." The prime minister hesitated to elaborate, merely calling the situation "serious" and "challenging." When asked specifically, "When will the war across [the border] be?" Vajpayee responded with an inconclusive "Just see what happens in the future."

It would be an understatement to say that the year 2002 has proven challenging for India. In order to deter further threats from Pakistan, India has adopted an unswerving strategy of resoluteness in facing challenges, investing in a reputation for strength. Given India's known superiority in conventional forces, this strategy should yield short-term deterrence equilibrium. However, the asymmetric level of information about each other's actual nuclear capability between both countries, as well as the level of uncertainty about future payoffs, could have a corrosive effect on investing in reputation.

Fearing the increased probability of nuclear conflict, Washington decided to intervene more decisively on behalf of India's concerns about alleged Pakistani-sponsored infiltrations by jehadi (Islamic militant) terrorist groups. The American interest in the issue was enlivened once it became apparent to American officials that Sunni extremist groups like Lashkar-e-Jhangvi (LeJ, Army of Jhangvi, named after one of the founders, Maulana Jhangvi), had

3. The full text of the speech is available at the Government of India's Ministry of External Affairs, <http://www.meadev.nic.in/speeches/pm-kupwara.htm>. 
ties to the al-Qaeda terrorist network. In May and August, Deputy Secretary of State Richard Armitage visited India. In August, Secretary of State Colin Powell also made a trip. While acknowledging the problem of border infiltrations by jehadi terrorists, Powell also manifested some concern about the fate of political prisoners in Kashmir.

Despite the declining state of his health, Vajpayee reciprocated Armitage's and Powell's visits on the eve of the anniversary of September 11. The active intervention by Washington officials, coupled with the macroeconomic realities of funding deployed troops, eventually prompted India to reconsider its massive military mobilization along the LOC. It is likely that given the outcome of the general election in Pakistan giving Islamist parties a critical share of the seats in Parliament, Indo-Pakistani relations will veer toward a more vitriolic trajectory.

\section{National Political Intrigue}

The ongoing tensions between India and Pakistan often overshadowed other critical internal political developments in India. At the national level, one of the most prominent changes was the stepping down of K. R. Narayanan as India's eleventh president. Under the country's constitutional provisions, Narayanan could have been renominated by the majority party in parliament. Despite his uneasy relationship with the ruling party, Narayanan remained the likely front-runner for renomination. However, the Bharatiya Janata Party (BJP) put forth A. J. P. Abdul Kalam as its surprising choice for president. Abdul Kalam's only other challenger was Lakshmi Saighal, the nominee from the leftist parties.

The BJP used this occasion to send a dual message. Abdul Kalam's nomination was pregnant with symbolism. Obviously, by nominating a Muslim, the BJP was sending a strong message for domestic consumption, namely that it was willing to shed its communal image. The nomination of Kalam, the architect of India's nuclear program, also highlighted the perception that India is trying to project internationally. On July 18, Abdul Kalam received $89.6 \%$ of the electoral college vote.

The virtually unobstructed election of Kalam to the presidency did not obscure more critical leadership problems in India. Over the last few years, Vajpayee's mounting health problems have posed a severe obstacle to his ability to govern. Moreover, the BJP's failed efforts to resolve the internal contradiction within its governing coalition came to the fore during a dramatic reshuffle of the cabinet. In its ever-insatiable hunger for hyperbole, the Indian press compared the current cabinet changes to those undertaken by 
Jawaharlal Nehru, namely the so-called Kamaraj Plan. ${ }^{4}$ In what will probably prove to be a completely inconsequential move, Defense Minister Jaswant Singh was ordered to trade ministerial portfolios with Finance Minister Yashwant Sinha. Having had three years to demonstrate their administrative mediocrity, it is unlikely that neither Singh nor Sinha will inspire the type of international confidence that India needs.

The cabinet reshuffle had a more important effect. In order to appease waning support within its Hindu-revivalist framework, Vajpayee promoted L. K. Advani to the post of deputy prime minister. Advani's promotion also coincided with the dismissal of Arun Jaitley from the cabinet. Given Vajpayee's obvious inability to provide vigorous leadership, Jaitley had been floated as his possible successor, particularly since he had done a credible job in his function as minister of law, justice, and company affairs. In that role, Jaitley had the unenviable task of shepherding a controversial anti-terrorism bill. The new law, referred to as the Prevention of Terrorism Ordinance (POTO) was passed in a joint session of parliament a week after it had been struck down at the Rajya Sabha (Upper House). Building upon existing antiterrorist provisions in the National Security Act of 1980 and the Terrorist and Disruptive Activities (Prevention) Act of 1987 (TADA), POTO was controversial because it allowed the executive to intercept various communications protocols. The law also burdened accused defendants with the presumption of guilt and provided for the secrecy of witnesses.

Although the passage of POTO outraged civil libertarians, Jaitley still remained among the BJP's most urbane and visible national figures. Jaitley's connection with the fight against Pakistani-sponsored terrorism also helped boost his profile. The criticism of POTO was muffled in light of other expedient developments. For instance, on April 1, 2002, a Delhi court declared Jaish-e-Mohammed's leader, Masood Azhar, and two other Pakistani nationals as the alleged perpetrators in the late 2001 attack on the Indian parliament. The apprehension of dangerous terrorists occurred concurrently with the passing of controversial anti-terrorist legislation. Making use of the legal provisions, 62 suspects accused of involvement in the violent riots in Gujarat were also detained.

The government's ability to fight terrorism was undermined by an unmanageable controversy surrounding Jaitley. He was severely chastised by the BJP's congressional opposition for claiming that the press had sensational-

4. The Kamaraj Plan (1963) refers to an administrative proposal drafted by Congress Party president H. Kamaraj, then chief minister of Madras. The plan called for central government cabinet ministers and state chief ministers of the Congress Party to resign their posts and to take on party organizational work at the local level. Although the proposal's desired goal fell short in its implementation, the Kamaraj Plan eventuated in some high-profile resignations by members of Jawaharlal Nehru's cabinet, and contributed to a brief renewal of party leadership. 
ized its reporting of the communal massacres in Gujarat. Due to the BJP's delicate connection with the issue of communalism, Jaitley rapidly became an inconvenient figure for the BJP. His ouster from the cabinet signaled protracted ambiguity as to who the likely successor to Vajpayee will be. The wisdom of this decision will become clearer once Vajpayee's mounting health problems destroy his existing resolve to remain in office.

\section{State Assembly Elections and Their Ramifications}

The year 2002 was also filled with intrigue relating to the outcome of various state assembly elections. India's largest state, Uttar Pradesh, held state assembly elections beginning on February 14. The elections took place against the backdrop of a provocative effort by the Vishwa Hindu Parishad (VHP, the World Hindu Council, an extremist Hindu chauvinist youth group) to begin construction of four temple gateways within 67 acres of land controlled by the Union government. The VHP threatened to carry out this task on March 12 to coincide with the Hindu festival of Shivratri. The dispute over the construction of a Hindu temple on the grounds of the demolished Babri Masjid precipitated some of India's most shocking communal violence in over a decade. On February 27, a train carrying hundreds of VHP kar sevaks (volunteers) from Ayodhya stopped at the Godhra railway station in Gujarat. The train was attacked and firebombed, leading to the death of 57 kar sevaks. This reprehensible attack was followed by indiscriminate revenge attacks against Muslims. Steven Wilkinson, a noted scholar of ethnic conflict in India, concluded, "[I]n many instances, the violence was targeted and highly organized, with rioters having apparently obtained detailed lists of Muslimowned houses, flats and shops." 5 Police inaction toward atrocities and other mounting evidence-such as the use of voter lists and other official documentation to target Muslim households and businesses-also suggest some level of state involvement in this massacre. ${ }^{6}$

Surprisingly, the violence in Gujarat did not mar the conduct of the state assembly elections in Uttar Pradesh, perhaps underscoring the role that the state has played in preventing violence. The electoral results, though, represented a noteworthy setback for the BJP. Although the party had been able to form a state government, it experienced an unexpected drop in electoral support, coming third in the polls and losing 41 seats in Uttar Pradesh's 403-

5. Steven Wilkinson, "Putting Gujarat in Perspective," Economic and Political Weekly, 37:17 (April 27-May 3, 2002), p. 1579.

6. Compelling evidence is provided for in a 70-page report released by Human Rights Watch, a respected human rights organization based in the United States. See Smita Narula et al., "We Have No Orders to Save You: State Participation and Complicity in Communal Violence in Gujarat," Human Rights Watch 14:3 (April 2002), <http://hrw.org/reports/2002>. 
member assembly. The Samajwadi Party (SP) received the largest percentage of seats, followed by the Bahujan Samaj Party (BSP). Accordingly, the BJP was forced to form a coalition with the BSP. The outcome of this alliance was that the BJP's chief minister, Rajnath Singh, was replaced by BSP leader Mayawati. After the elections, a major crisis was averted once it became clear that the proposed start of temple construction would undermine the BJP's coalition government at the federal level.

One of Mayawati's first legislative acts as chief minister was to overturn Rajnath Singh's affirmative action program used to hire public employees. Rajnath Singh's measure had been ensnared in legal challenges, which had prevented the potential hiring of thousands of lower-caste public employees. Even in the vaudevillian context of Uttar Pradesh's politics, Rajnath Singh's scheme was illogical, as the state government faced a staggering fiscal crisis that prevented it from paying its existing public employees. More alarmingly, Mayawati's repeal will enable the Uttar Pradesh state government to hire those individuals, thus certainly aggravating its fiscal woes.

State assembly elections were controversial, even in their absence. The state of Gujarat, one of India's magnets for foreign direct investment and portfolio equity investment, became the bellwether of the worst aspects of Indian politics. Citing the provisions in Article 174(1) of India's Constitution-which limit the prorogation of a sitting legislature for a period no longer than six months-Gujarat's Chief Minister Narendra Modi cynically saw the dissolution of the state assembly following the February massacres in his state as an opportunity to call early elections. A presidential reference to Modi's request tested India's constitutional limits, prompting the federal Election Commission to ask the Supreme Court to decide whether the presidential reference on the holding of the elections was lawful. Believing that the situation in Gujarat during this period of communal turmoil was incompatible with a call for early elections, the Election Commission instead argued that Article 324 of the Indian Constitution-which grants this body the responsibility to oversee free and fair elections-should override the provisions in Article 174(1).

The potential for communal tensions in Gujarat was heightened when members of an unknown Muslim radical group, called Tehreek-e-Kisaas (Movement for Revenge), seized the Akshardham Temple in Gandhinagar on September 25. After the group killed 28 worshippers, Indian special forces regained control of the temple. Not wanting to further tarnish the central government's international image further, the attack against the temple did not culminate with retaliatory attacks against Muslims, once again indicating state complicity in the March massacre. Instead, a nationwide hartal (strike) was held to mourn the victims. Nevertheless, in an election fraught with appeals to Hindu chauvinism, the BJP went on to obtain a categorical victory 
once the Gujarat state assembly election was held in December. The BJP's stunning electoral victory in Gujarat may embolden the party in future contests.

The threat of communal violence has overshadowed equally critical structural problems in India's polity. Inconsistent government policies, often rooted in populist political rhetoric or provincial power brokering, are widely viewed as the main threat to India's subnational economic growth. According to a recent study by this author, India has the largest ratio of subnational fiscal deficits as a proportion of total subnational revenue among all emerging markets. ${ }^{7}$ In a practice that will have long-term effects on economic development, states in India have shifted the direction of subnational expenditure from capital expenditure to covering current expenditures. Within this context, the outcome of various state assembly elections could have severe implications for India's subnational economic development. Among India's largest states, Punjab has one of the poorest records of fiscal discipline. The BJP-Shiromani Akali Dal coalition government, under the leadership of Prakash Singh Badal, ran a fiscal deficit nearing $40 \%$ of Punjab's net state domestic product.

Prior to the February elections in Punjab, Badal tried to consolidate support for the ruling coalition through a redistributive program called Sangat Darshan (A Relevant Vision). The scheme redirected development and welfare expenditures from contributions by the state's rural development fund. Following a polarizing electoral campaign, the state assembly elections in Punjab provided some hope for the median voter. Running on a platform of fiscal restraint and competent leadership, the Congress Party mustered a narrow margin of victory, securing a mere $36.5 \%$ of the vote. The BJPShiromani Akali Dal coalition government lost a combined 47 seats in Punjab's 117-member state assembly.

The results of the state assembly elections offered mixed messages about the capacity of the BJP to continue to head a multiparty coalition at the center. The defeats of the BJP in Uttar Pradesh and Punjab were also coupled with Congress Party victories in state assembly elections in Uttaranchal and Manipur. This trend signals a gradual disintegration of the BJP's hold at the regional level and a revival of the Congress Party. On the eve of the BJP-led National Democratic Alliance in 1998, the BJP ruled in eight states. By the end of 2002, only four state governments in India (Gujarat, Orissa, Himachal Pradesh, and Jharkhand) were headed by the BJP or by a BJP-supported alliance. In terms of regional leadership, the BJP can only count on Gujarat's

7. See Lawrence Sáez, "Globalization and Federalism in Emerging Markets," Yale Center of International Studies, Globalization and Self-Determination Working Paper Series, 2002. 
controversial chief minister, Narendra Modi, as its most recognizable regional figure at the national level.

The state assembly elections also highlighted the continuing trend of political redemption among India's most colorful and disgraced politicians. The Uttar Pradesh polls enabled the revival of Mayawati in her third stint as chief minister. In another surprising revival of political fortunes, Jayalalitha, the repeatedly disgraced general secretary of the All India Anna Dravida Munnetra Kazhagam (AIADMK) and former chief minister of Tamil Nadu, won a constituency election in Andipatti. It is only in the midst of this political leadership vacuum that a vacuous quasi-politician like Congress Party leader Sonia Gandhi can appear to be a refreshing alternative.

The most widely anticipated state assembly elections of the year, though, took place in October, when the troubled state of Jammu and Kashmir held its first such elections since 1987. The inauspicious prelude to the elections included the murder of Abdul Ghari Lone, a moderate leader in Kashmir's largest separatist alliance, the All-Party Hurriyat Conference. Having publicly criticized Pakistan for interfering in Kashmiri affairs, Lone was also one of Kashmir's most visible opponents of political violence. The assassination was carried out by gunmen dressed in police uniforms, thus signaling the sophisticated level of planning by the murderers.

Given the continuing conflict between India and Pakistan, the state assembly elections carried potentially international repercussions. In the belief that legitimate state assembly elections would add credibility to India's rule over the region, the principal Kashmiri separatist parties boycotted the election. Various fringe Kashmiri separatist terrorist groups desperately tried to scare voters from the polls, either through murder or intimidation. On September 11, Kashmiri terrorists murdered Mustaq Ahmad Lone, the state's law minister. The elections were carried out in an ambience of intimidation, including reports that some police officers had forced some unwilling voters to the polling stations.

The outcome of the elections in Jammu and Kashmir was relatively inconsequential; their significance was that they took place at all. Nevertheless, in keeping with a nationwide rejection of the BJP and its allies, the National Conference, headed by Farooq Abullah and his son Omar Abdullah, suffered its worst electoral performance ever in the state. Although the National Conference won a plurality of the vote, it was not able to form a government. Instead, the People's Democratic Alliance (the third largest vote-getter in the election) was able to form a coalition government with the Congress Party. Despite the fact that more than 800 people died in election-related violence, the voter turnout was high, approaching $46 \%$. In light of previous rigged elections in Jammu and Kashmir, this was perhaps the most notable example of a growing desire by Kashmiris for peace in the region. 


\section{Economy}

Diplomatic relations between India and Pakistan appear to have followed a predictable pattern of escalation occasioned in large measure by terrorist attacks on Indian soil followed by a brief diffusion of tensions in response to external diplomatic pressure. Surprisingly, little effort has been made to strengthen the economic ties between South Asian nations and the United States. For instance, India is only the United States's 25th largest trading partner.

In a January 28 speech before the American Chamber of Commerce in India and the Indo-American Chamber of Commerce, U.S. Ambassador Robert Blackwill described the trend in Indo-U.S. trade as being "as flat as a chapati." Blackwill's colorful simile serves to remind us that trade could be an optimal tool for increased diplomatic cooperation on other fronts. Moreover, greater economic integration should have a salutory effect upon India's sagging macroeconomic performance.

India's economic performance in 2002 improved dramatically after a disastrous year. In the United Nation's Global Economic Outlook, India's economic growth was projected to be $5.7 \%$ for 2002. The Asian Development Bank's (ADB) Asian Economic Outlook forecast a 6.0\% growth in GDP and a decline in the ratio of fiscal deficit to GDP of 5.3.9 The recovery in the Indian economy can be traced to a dramatic reversal in export competitiveness. The ADB forecast a substantial increase in merchandise trade growth from the previous year. Merchandise export growth is anticipated to grow to $11 \%$ in 2002 , compared to $-1 \%$ in 2001 . Similarly, merchandise import growth in 2002 reached a respectable $13 \%$ growth in contrast to $-0.9 \%$ in 2001.

India continues to enjoy a comparative advantage in the delivery of information technology (IT) enabled services. The software and IT services industries, India's fastest growing sectors, grew to 30,000 Rs crore $(\$ 6.2$ billion) in 2002 , compared to 28,350 Rs crore ( $\$ 5.8$ billion) a year earlier. Other optimistic economic indicators included the increase in foreign direct investment flows to India. Foreign direct investment inflows were projected at a respectable $\$ 4.3$ billion in 2002, up from a modest $\$ 3.2$ billion in 2001 .

The long-term prospects for growth, though, are less definite. As the United States shifts its attention away from the region, it is less likely that whatever support India has received during 2002 will continue. Domestically, a decline in public spending may affect consumption demand. Reflecting growing consumer uncertainty and a tepid pace of industrial production,

8. The full text of the speech can be found at <http://usembassy.state.gov/posts/pk1/ wwwh02013003.html>.

9. See <http://www.adb.org/documents/books/ADO/2002/ind.asp>. 
by the end of October the Reserve Bank of India (RBI) had already trimmed its forecast for economic growth from $6.5 \%$ to $5.5 \%$. The RBI released its revised growth estimate just as the government released its own projection of $8 \%$ annual GDP growth until 2007. Internationally, the virtual derailment of India's sputtering privatization program and the continuing sectarian violence in some of India's most prominent states could only have a detrimental effect on foreign investors' confidence. 